\title{
Altered Trace Elements Levels in Hair of Prostate Cancer Patients
}

\author{
Saleh A. K. Saleh ${ }^{1,3, *}$, Heba M. Adly ${ }^{1}$ and Anmar M. Nassir ${ }^{2}$
}

${ }^{1}$ Biochemistry Department, Faculty of Medicine, Umm Al-Qura University, Makkah, KSA

${ }^{2}$ Department of Surgery, Faculty of Medicine, Umm Al-Qura University, Makkah, KSA

${ }^{3}$ Oncology Diagnostic Unit, Faculty of medicine, Ain Shams University, Cairo, Egypt

\begin{abstract}
Background: Deficiency or excess of trace elements can induce metabolic disorders and dysregulate cell growth, and even lead to mutations and tumorigenesis. Many reports have indicated a direct association between micronutrient deficiency and cancer mortality. Prostate cancer is the sixth most common cancer among men in Saudi Arabia, yet there are few studies of the association between trace element levels and prostate cancer in the country.
\end{abstract}

Objective: This study aimed to explore the association between concentrations of select hair trace elements, including selenium $(\mathrm{Se})$, zinc $(\mathrm{Zn})$, copper $(\mathrm{Cu})$, manganese $(\mathrm{Mn})$, and iron $(\mathrm{Fe})$, as long-term indicators, and tumorigenesis of prostate cancer in Saudi Arabia. 1.2 Patients and Methods: The study included 58 patients with prostate cancer, 64 with benign prostatic hyperplasia (BPH), and 52 healthy controls. Full history and clinical data were recorded for all subjects. Hair samples were collected from the nape of all subjects, and levels of $\mathrm{Se}, \mathrm{Zn}, \mathrm{Cu}$, $\mathrm{Mn}$, and Fe were analyzed by inductively-coupled plasma mass spectrometry.

Results: Hair Se and $\mathrm{Zn}$ levels of prostate cancer patients were significantly lower compared to BPH and healthy groups whereas $\mathrm{Cu}, \mathrm{Mn}$, and Fe levels were significantly high. Hair Se and $\mathrm{Zn}$ levels were significantly lower in metastatic prostate cancer patients than in localized cancer patients whereas mean hair levels of $\mathrm{Cu}, \mathrm{Mn}$, and Fe were not significantly different among these patients.

Conclusion: Prostate cancer may be associated with trace element-mediated metabolic disorders. Low levels of $\mathrm{Se}$ and $\mathrm{Zn}$ and high levels of $\mathrm{Cu}, \mathrm{Mn}$, and $\mathrm{Fe}$ appear to be associated with its tumorigenesis. Additional prospective studies are warranted to confirm the inverse correlation between Se and $\mathrm{Zn}$ levels and prostate cancer.

Keywords: Trace elements; Benign prostatic hyperplasia; Prostate cancer; Saudi Arabia

\section{Introduction}

Prostate cancer is the second common male cancers worldwide with approximately 1,111,700 annual new cases [1] and the sixth common male cancer in Saudi Arabia [2,3]. Epidemiological studies suggest that environmental factors enhance prostate cancer progression [4], as do lifestyle choices like diet, alcohol, and smoking $[5,6]$.

The realization of the trace element roles in human has increased through the past five decades [7]. Trace elements augment the immune system, and their imbalance can promote metabolic disorders, cause cell proliferation abnormalities, and promote tumorigenesis $[8,9]$. Fluctuating concentrations of trace element ions can influence antioxidant enzyme activity; because these elements complex with enzymes responsible for antioxidant protection [10], oxidative processes intensify when there is an imbalance of trace elements. Environmental trace elements including selenium $(\mathrm{Se})$, zinc $(\mathrm{Zn})$, copper $(\mathrm{Cu})$, and iron $(\mathrm{Fe})$ have been implicated in various types of cancer [11,12]. Studies have shown elevated levels of $\mathrm{Cu}$ in bladder, breast, prostate, and liver cancers [13], and the $\mathrm{Cu} / \mathrm{Zn}$ ratio is used to assess patient prognosis [14,15]. Additionally, several studies showed that $\mathrm{Zn}$ supplement may protect against free radical damage [16] or that $\mathrm{Zn}$ levels are decreased in patients with certain malignancies [17]. Se and $\mathrm{Zn}$ levels have been correlated to prostate cancer risk [18,19]; higher Se levels are related to a lower risk of many types of neoplasms, including lung, colorectal, prostate and possibly bladder [20,21]. Selenium is thought to inhibit carcinogenesis through many mechanisms including reduction of oxidative stress and inflammation, enhancement of the immune response, induction of apoptosis and cell cycle arrest as well as transactivation of DNA repairing genes [22,23].
Conventional blood analysis can indicate the trace elements content at the day of sample or a few days prior to the blood analysis [24]; however, trace element analysis in hair can determine the metal content for the past 3-6 months prior to analysis. Hair analysis can overcome fluctuation due to daily food intake and may provide noninvasive, low cost and measurement of large number of elements at a time. On the other hand, some limitations may interfere the accuracy of results as age, gender, ethnicity and inter-individual variability [25]. There is an increased interest towards effectiveness of trace elements on metabolic pathways $[26,27]$. This study aimed to explore the alterations of the trace elements $\mathrm{Se}, \mathrm{Zn}, \mathrm{Cu}, \mathrm{Mn}$, and Fe levels in hair of prostate cancer patients in Saudi Arabia.

\section{Patients and Methods}

This study included 58 patients with prostate cancer (mean age 71.1 \pm 5.4 years), 64 benign prostatic hyperplasia (BPH) patients (mean age $69.3 \pm 7.4$ years), and 52 healthy male individuals (mean age $68.8 \pm$ 7.8 years) who were randomly selected among volunteers of matched

*Corresponding author: S. A. K. Saleh, Department of Medicine, Umm Al-Qura University, Makkah, Makkah Saudi Arabia. Tel: 966125501000 E-mail: Saleh-A-S@hotmail.com

Received January 16, 2017; Accepted February 18, 2017; Published February 26, 2017

Citation: Saleh SAK, Adly HM, Nassir AM (2017) Altered Trace Elements Levels in Hair of Prostate Cancer Patients. J Cancer Sci Ther 9: 336-339. doi: 10.4172/1948-5956.1000438

Copyright: (c) 2017 Saleh SAK, et al. This is an open-access article distributed under the terms of the Creative Commons Attribution License, which permits unrestricted use, distribution, and reproduction in any medium, provided the original author and source are credited. 
socio-economic status and who did not have any known disease and had no history of alcohol or drug abuse. Participated individuals who were taking elements supplementation for the past three months were precluded from the study. Prostate cancer patients were classified into localized $(\mathrm{n}=46)$ and metastatic $(\mathrm{n}=12)$. $\mathrm{BPH}$ and healthy male individuals $(\mathrm{n}=116)$ were grouped as controls. Prostate cancer patients underwent digital rectal examination, trans-rectal ultrasonography guided biopsy of the prostate, computed tomography scanning of the pelvis, bone scanning, and histopathological examination to assess metastatic disease and determine disease stage.

\section{Trace Elements Analysis}

Scalp hair specimens were collected, weighed, and stored at $25^{\circ} \mathrm{C}$ till washed, digested and analyzed within 3 weeks of sample collection. For each sample of $5 \mathrm{mg}$ hair, successive washes of acetone, deionized water and $0.5 \%$ Triton X-100 solution were performed $[28,29]$ then hair sample was digested by nitric acid, hydrogen peroxide, and deionized water followed by dilution to $10 \mathrm{~mL}$ [30]. Analysis of hair trace elements (Se, $\mathrm{Zn}, \mathrm{Cu}$ and $\mathrm{Mn}$ ) concentrations were carried out by ICP-MS (Perkin Elmer 7300, Perkin Elmer, USA), according to manufacturer's instructions (Figures 1 and 2).

\section{Statistical Analysis}

Data are expressed as the mean \pm standard deviation (SD) for different studied parameters and possible associations between them. Data between groups were compared using one-way analysis of variance (ANOVA), and the differences between means of two of three studied groups were analysed using an independent-sample t-test. The level of significance was set at a $\mathrm{p}<0.05$. IBM SPSS Statistics v20 (IBM, USA) was used for the statistical analyses.

\section{Results}

No statistically significant difference between prostate cancer patients and controls was found with respect to age, (Table 1). Trace elements levels in different groups were compared and presented in Table 2. Mean Se and Zn levels in the hair of the prostate cancer patients were significantly lower compared to $\mathrm{BPH}$ and healthy groups $(\mathrm{p}<0.005)$ whereas the mean levels of hair $\mathrm{Cu}, \mathrm{Mn}$, and $\mathrm{Fe}$ were significantly higher in the prostate cancer group than the $\mathrm{BPH}$ and healthy groups $(\mathrm{p}<0.005)$. Moreover, mean levels of hair Se and $\mathrm{Zn}$ were significantly lower in patients with metastatic prostate cancer compared to those with localized prostate cancer $(\mathrm{p}<0.005)$, whereas mean hair levels of $\mathrm{Cu}, \mathrm{Mn}$ and $\mathrm{Fe}$ were not significantly different $(\mathrm{p}>0.05)$.

\section{Discussion}

Trace elements are essential structural components of biological tissues or molecules, but their roles in the development or inhibition of cancer are complex. These elements have been the subject of investigation because of their biological necessity as well as their toxicity at concentrations that exceed physiological levels [31].

Most of the previous studies explored the relationship between prostate cancer risk and trace element concentrations in the blood $[32,33]$. To the best of our knowledge, this is the first study to examine the association between concentration of some hair trace elements (Se, $\mathrm{Zn}, \mathrm{Cu}, \mathrm{Mn}$, and $\mathrm{Fe}$ ) and the risk of prostate cancer in Saudi Arabia.

Many reports indicated that low levels of Se may correlate with carcinogenesis and is a risk factor of cancer [34]. Our results revealed that hair Se concentrations were significantly decreased in prostate cancer patients than in BPH patients and healthy individuals. Se complexes with blood proteins and plays a substantial antioxidant role by eliminating free radicals. It is also reported that Se may prevent tumorigenesis in otherwise higher-risk patients [34]

$\mathrm{Zn}$ is an essential metal required for the synthesis of DNA, RNA, and proteins, as well as for enzymatic activity of $\mathrm{Zn}$-containing enzymes [35]. It is known to be a physiological antagonist of copper and may be responsible for the hypozincemia observed alongside hypercupremia in malignancies [36]. Our study indicated a statistically significant decrease of hair $\mathrm{Zn}$ concentrations in prostate cancer patients compared to control individuals. Additionally, $\mathrm{Zn}$ deficiency increased the risk of prostate cancer, which is consistent with previous studies $[37,38]$.

A direct interference of $\mathrm{Zn}$ with intestinal absorption of $\mathrm{Cu}$ can result in higher levels of free $\mathrm{Cu}$ that can then displace $\mathrm{Zn}$ from metallothionein, because of copper's high affinity for this protein. This postulated mechanism may explain the decrease observed in hair $\mathrm{Zn}$ concentrations that accompanied elevated $\mathrm{Cu}$ concentrations measured in this study.

Iron is an essential trace element that is crucial to normal cell functioning, and its deficiency or excess is associated with several diseases [39]. Iron levels are significantly elevated in malignant glioma patients [9], and it is possible that pathogenesis is mediated by the direct effect of iron overload on the formation of hydroxyl-free radicals from hydrogen peroxide and superoxide via the Fenton and HaberWeiss reactions [39]. Our results indicated that hair Fe concentrations were significantly elevated in prostate cancer patients compared to $\mathrm{BPH}$ patients as well as healthy individuals.

Manganese is an essential trace element in the body that has several biochemical and chemical characteristics similar to iron. Some

\begin{tabular}{|c|c|c|c|c|}
\hline & \multirow{2}{*}{$\begin{array}{c}\text { Prostate } \\
\text { cancer group }\end{array}$} & \multicolumn{3}{|c|}{ Control groups } \\
\hline & & BPH & Healthy & Total \\
\hline Number (n) & 58 & 64 & 52 & 116 \\
\hline Age (year) & $71.1 \pm 5.4$ & $69.3 \pm 7.4$ & $66.8 \pm 7.8$ & $68.1 \pm 7.5$ \\
\hline Smoking (\%) & $19(32.8 \%)$ & $25(39.1 \%)$ & $11(21.2 \%)$ & $36(31.0 \%)$ \\
\hline $\begin{array}{c}\text { Alcohol } \\
\text { consumption (\%) }\end{array}$ & $\begin{array}{c}0 \\
(0 \%)\end{array}$ & $\begin{array}{c}0 \\
(0 \%)\end{array}$ & $\begin{array}{c}0 \\
(0 \%)\end{array}$ & $\begin{array}{c}0 \\
(0 \%)\end{array}$ \\
\hline
\end{tabular}

Table 1: General Characteristics of study population

\begin{tabular}{|c|c|c|c|c|c|}
\hline \multirow{3}{*}{ Parameter } & \multirow{3}{*}{$\begin{array}{c}\text { Prostate cancer group } \\
\text { Mean } \pm S D\end{array}$} & \multicolumn{3}{|c|}{ Control groups } & \multirow{3}{*}{$\begin{array}{c}\mathbf{P} \\
\text { value }\end{array}$} \\
\hline & & \multirow{2}{*}{$\begin{array}{c}\text { BPH } \\
\text { Mean } \pm S D\end{array}$} & \multirow{2}{*}{$\begin{array}{c}\text { Healthy } \\
\text { Mean } \pm S D \\
\end{array}$} & \multirow{2}{*}{$\begin{array}{c}\text { Total } \\
\text { Mean } \pm S D\end{array}$} & \\
\hline & & & & & \\
\hline $\operatorname{Se}(\mu g / g)$ & $7.3 \pm 1.4^{\mathrm{a}}$ & $10.8 \pm 1.9$ & $11.5 \pm 2.1$ & $11.2 \pm 2.0^{\mathrm{a}}$ & $<0.005^{\mathrm{a}}$ \\
\hline $\mathrm{Zn}(\mu \mathrm{g} / \mathrm{g})$ & $3.1 \pm 0.7^{b}$ & $4.2 \pm 0.6$ & $4.4 \pm 0.4$ & $4.3 \pm 0.5^{b}$ & $<0.005^{b}$ \\
\hline $\mathrm{Cu}(\mu \mathrm{g} / \mathrm{g})$ & $0.097 \pm 0.02^{c}$ & $0.072 \pm 0.01$ & $0.070 \pm 0.01$ & $0.071 \pm 0.01^{c}$ & $<0.005^{c}$ \\
\hline $\mathrm{Mn}(\mu \mathrm{g} / \mathrm{g})$ & $0.083 \pm 0.02^{\mathrm{d}}$ & $0.062 \pm 0.03$ & $0.058 \pm 0.03$ & $0.060 \pm 0.03^{d}$ & $<0.005^{d}$ \\
\hline $\mathrm{Fe}(\mu \mathrm{g} / \mathrm{g})$ & $1.0 \pm 0.28^{e}$ & $0.85 \pm 0.16$ & $0.82 \pm 0.17$ & $0.84 \pm 0.16^{e}$ & $<0.005^{e}$ \\
\hline
\end{tabular}

Table 2: Hair trace elements concentrations in study population. 


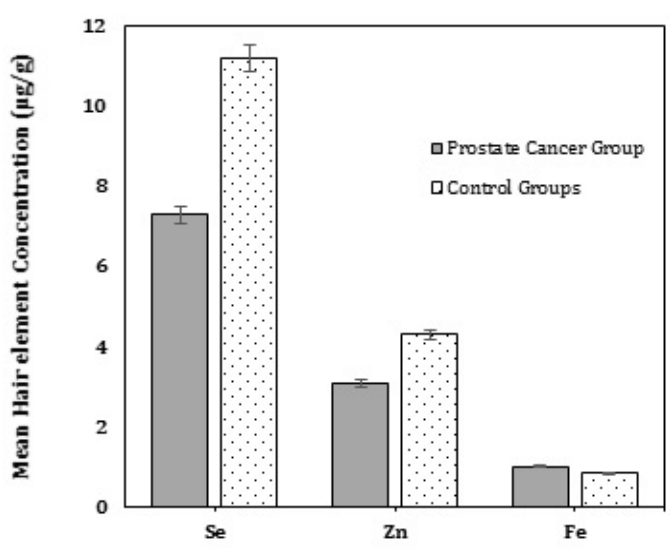

Figure 1: Hair trace elements (Se, $\mathrm{Zn}$, and Fe) concentrations in study population.

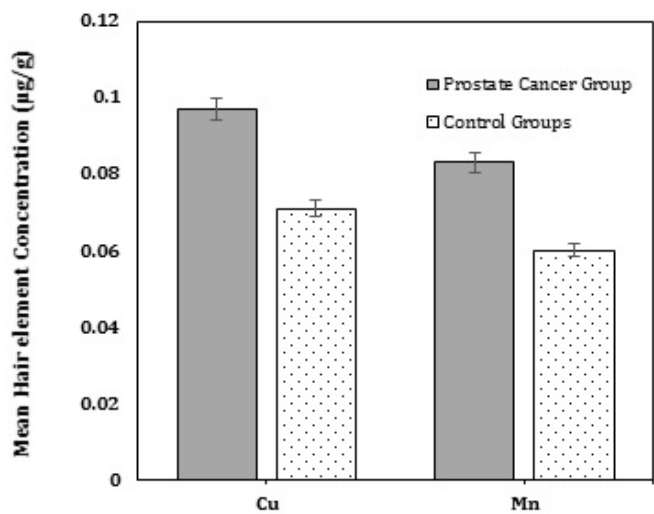

Figure 2: Hair trace Hair trace elements ( $\mathrm{Cu}$ and $\mathrm{Mn}$ ) concentrations in study population.

previous studies revealed a metabolic interaction between the Fe and Mn, especially at the level of intestinal absorption [40,41]. In the present study, we observed a significant difference in the concentration of hair Mn levels in prostate cancer patients compared to control group.

\section{Conclusion}

Prostate tumorigenesis may be linked to metabolic disorders of trace elements. Low levels of hair Se and $\mathrm{Zn}$ and high hair concentration of $\mathrm{Cu}, \mathrm{Mn}$, and Fe appear to be associated with the risk of prostate cancer in Saudi Arabia. Further prospective studies are needed emphasizing the alterations of trace element levels in both benign and malignant prostate tumors. The relative transport-proteins of those trace elements may be the potential pathognomonic biomarkers of prostate cancer. Additionally, the mechanism of trace element-mediated carcinogenesis and variation of the relevant transport-proteins in prostate cancer are worth further investigation.

\section{Ethical Considerations}

The Ethical Research Committee at the Faculty of Medicine, Umm Al Qura University, and affiliated hospitals approved this study. Informed consent was obtained from all patients and healthy subjects; the aim of the study and the procedures that would be required were described to them beforehand. All subjects were assured that they could choose to discontinue their participation in the study without jeopardizing the medical care being given to them, including treatment and follow-up.

\section{References}

1. American Cancer Society (2015) Global cancer facts and figures, (3rdedn). Atlanta: American Cancer Society.

2. Al-Madouj A, Eldali A, Al-Zahrani A (2011) Ten-year cancer incidence among nationals of the GCC states 1998-2007. Riyadh: Gulf Center for Cancer Control and Prevention; King Faisal Specialist Hospital and Research Center

3. Mahmood A, Te OB, Urcia JC, Khan A (2012) Tumor registry annual report 2011. Riyadh: King Faisal Specialist Hospital and Research Center.

4. Menegaux F, Anger A, Randrianasolo H, Mulot C, Laurent-Puig P, et al. (2014) Epidemiological study of prostate cancer (EPICAP): a population-based case control study in France. BMC Cancer 14:106.

5. Ferrís-i-Tortajada,a J, Berbel-Tornero O, Garcia-i-Castell J, López-Andreu J, Sobrino-Najul E, et al. (2011) Non-dietary environmental risk factors in prostate cancer. Actas Urol Esp 35(5): 289-295.

6. Huncharek M, Sue Haddock K, Reid R, Kupelnick B (2010) Smoking as a risk factor for prostate cancer: A meta-analysis of 24 prospective cohort studies. Am J Public Health 100(4): 693-701.

7. Yavuz B, Ertugrul DT, Cil H, Ata $\mathrm{N}$ et al (2009) Increased levels of 25 hydroxyvitamin $D$ and 1,25-dihydroxyvitamin $D$ after rosuvastatin treatment: $A$ novel pleiotropic effect of statins? Cardiovasc Drugs Ther 20: 312-20.

8. Navarro Silvera A, Rohan TE (2007) Trace elements and cancer risk: A review of the epidemiologic evidence. Cancer Causes Control 18: n7-27.

9. Arslan M, Demir H, Arslan H, Goklalp AS, Demir C (2011) Trace elements, heavy metals and other biochemical parameters in malignant glioma patients. Asian Pac J Cancer Prev 12: 447-451.

10. Krishnamurthy P, Wadhwani A (2012) Biochemistry, genetics and molecula biology » "Antioxidant Enzyme", El-Missiry Md A (Ed). Croatia: InTech; 2012: 410.

11. Dawood SD, Ashoor ZF (2010) A study of Serum Zinc, Iron, Selenium, and Copper levels in patients with bladder cancer. Iraqi J Ca Med Gen 3(1): 40-45

12. Prashanth L, Kattapagari K, Chitturi R, Baddam V, Prasad L (2015) A review on role of essential trace elements in health and disease. J NTR Univ Health Sci 4: 75-85.

13. Guo K, Zhang Z, Wang J, Gao S, Liu J, et al. (2015) Variation of urinary and serum trace elements $(\mathrm{Ca}, \mathrm{Zn}, \mathrm{Cu}, \mathrm{Se})$ in bladder carcinoma in China. Asian Pacific J Cancer Prev 13: 2057-61.

14. Kaba M, Pirinççi N, Yüksel M, Geçit J, Güneş M, et al. (2015) Serum levels of trace elements in patients with testicular cancers. Int Braz J Urol 41(6): 1101 1107.

15. Mazdak H, Yazdekhasti F, Movahedian, Mirkheshti, Shafieian M (2010) The comparative study of serum iron, copper, and zinc levels between bladder cancer patients and a control group. Int Urol Nephrol 42: 89-93.

16. Bosland MC, Kato I, Zeleniuch-Jacquotte A, Schmoll J, Rueter EE, et al. (2013) Effect of soy protein isolate supplementation on biochemical recurrence of prostate cancer after radical prostatectomy. JAMA 310(2): 170-178.

17. Joazeiro CA, Weissman AM (2000) RING finger proteins: Mediators of ubiquitin ligase activity. Cell 102: 549-552.

18. Platz EA, Helzlsouer KJ (2001) Selenium, zinc, and prostate cancer. Epidemio Rev 23: 93-101.

19. Chan J, Oh W, Xie W, Regan M, Stampfer M, et al. (2009) Plasma selenium manganese superoxide dismutase, and intermediate-or high-risk prostate cancer. J Clin Oncol 27: 3577-3583.

20. Rayman M (2005) Selenium in cancer prevention: A review of the evidence and mechanism of action. Proc Nutr Soc 64: 527-542.

21. Brinkman M, Buntinx F, Muls E, Zeegers M (2006) Use of Selenium in chemoprevention of bladder cancer. Lancet Oncol 7: 766-74.

22. Margalit D, Jordahl K, Werner L, Wang X, Lee M, et al. (2015) Germline 
Citation: Saleh SAK, Adly HM, Nassir AM (2017) Altered Trace Elements Levels in Hair of Prostate Cancer Patients. J Cancer Sci Ther 9: 336-339. doi: $10.4172 / 1948-5956.1000438$

variation in superoxide dismutase-2 (SOD2) and survival outcomes after radiation therapy for prostate cancer: Results from a test and validation se analysis. Clin Genitourin Canc 13(4): 370-377.

23. Smith ML, Lancia JK, Mercer TI (2004) Selenium compounds regulate p53 by common and distinctive mechanisms. Anticanc Res 24: 1401-1408.

24. Wang C, Huang C, Chou S, Lin C, Liau S, et al. (1994) Studies on the concentrations of arsenic, selenium, copper, zinc and iron in the hair of blackfoot disease patients in different clinical stages. Eur $\mathrm{J}$ Clin Chem Clin Biochem 32: 107-111.

25. Wang C, Chang W, Zeng W, Lin C (2005) Concentrations of calcium, copper iron, magnesium, potassium, sodium and zinc in adult female hair with different body mass indexes in Taiwan. Clin Chem Lab Med 43(4): 389-393.

26. Chojnacka K, Zielinska A, Gorecka H, Dobrzanski Z, Gorecki H (2010) Reference value for hair minerals of Polish students. Env Toxicol Pharm 3 : $52-56$

27. Fatani S, Saleh S, Adly H, Abdulkhaliq A (2016) Trace element alterations in the hair of diabetic and obese women. Biol Trace Elem Res 174(1): 32-39.

28. Chatt A, Katz SA (1988) The biological basis for trace elements in hair applications in biomedical and environmental sciences. New York: $\mathrm{VCH}$ Publishers.

29. Gammelgaard B, Peters K, Menne T (1991) Reference values for the nicke concentration in human fingernails. J Trace Elem Electrolytes Health Dis 5:121-123.

30. Mehra R, Juneja M (2005) Elements in scalp hair and nails indicating metal body burden in polluted environment. J Sci Ind Res 64: 119-124

31. Zowczak M, Iskra M, Torlinski L, Cofta S (2001) Analysis of serum copper and zinc concentration in cancer patients. Biol Trace Elem Res 82: 1-8.
32. Shahar S, Shafurah S, Hasan Shaari NS, Rajikan R, Rajab NF, et al. (2011) Roles of dietary, lifetime physical activity and oxidative DNA damage in the occurrence of prostate cancer among men in Klang Valley. Asian Pac J Canc Prev 12: 1-6.

33. Adaramoye OA, Akinloye O, Olatunji IK (2010) Trace elements and vitamin E status in Nigerian patients with prostate cancer. Afr Health Sci 10: 2-8.

34. Wallace K, Kelsey KT, Schned A, Morris JS, Andrew AS, Karagas MR (2009) Selenium and risk of bladder cancer: A population-based case-control study. Cancer Prev Res 2: 70-73.

35. Cousins RJ, Blanchard RK, Moore JB, Cui L, Green CL, et al. (2003) Regulation of zinc metabolism and genomic outcomes. J Nutr 133: 1521S-1526S.

36. Milde D, Novak O, Stuka V, Vyslouil K, Machaek J (2001) Serum levels of selenium, magnesium, copper, and iron in colorectal cancer patients. Biol Trace Elem Res 79: 107-114.

37. Costello LC, Franklin RB (2011) Zinc is decreased in prostate cancer: An established relationship of prostate cancer. J Biol Inorg Chem 16: 3-8.

38. Epstein MM, Kasperzyk JL, Andren O, Giovannucci EL, Wolk A, et al. (2011) Dietary zinc and prostate cancer survival in a Swedish cohort. Am J Clin Nutr 93: $586-593$.

39. Dayani PN, Bishop MC, Black K, Zeltzer PM (2004) Desferoxamine (DFO)mediated iron chelation: Rationale for a novel approach to therapy for brain cancer. J Neurooncol 67: 367-377.

40. Collins J, Prohaska J, Knutson M (2010) Metabolic crossroads of iron and copper. Nutr Rev 68(3): 133-147.

41. Kim J, Buckett $P$, Wessling-Resnick $M$ (2013) Absorption of manganese and iron in a mouse model of hemochromatosis. PLoS One 8(5): e64944. 